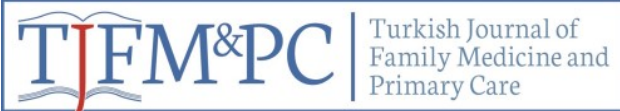

Original Research / Özgün Araştırma

\title{
Creutzfeldt-Jacob Disease, As a Rare Cause of Dementia Should Not be Forgotten: Single-Center Experience
}

\section{Tek Merkez Deneyimi: Unutulmaması Gereken Nadir Bir Demans Nedeni Olarak Creutzfeldt-Jakob Hastalığ}

\author{
Turgay Demir ${ }^{*}$, Kezban Aslan Kara ${ }^{l}$, Şebnem Bıçakçıl, Mehmet Taylan Peköz', Mehmet Balal ${ }^{1}$, Meltem \\ Demirkıran $^{l}$, Hacer Bozdemir ${ }^{l}$
}

\begin{abstract}
Introduction: Dementia, which is an important public health problem, is divided into two groups as primary and secondary dementia. Creutzfeldt-Jakob disease (CJD), which is rarely seen, is a secondary cause of dementia with a rapidly progressive course. It is a fatal neurodegenerative disorder of infectious spongiform encephalopathy that can affect humans and animals. Sporadic CJD is the most common type that can present in four forms and has typical clinical presentations of progressive cognitive impairment, myoclonus, and ataxia. We aimed to discuss the demographic, clinical, and laboratory findings of CJD cases diagnosed in the neurointensive care unit. Methods: Sixteen patients were included in this retrospective study. Age, sex, complaints on admission, duration from symptom onset to mortality, neurologic examination, brain magnetic resonance imaging (MRI), electroencephalography (EEG), and the protein 14.3.3 status of the cerebrospinal fluid (CSF) were recorded. Results: The mean age was $61.18 \pm 9.1$ years (range, 37-73 years), and the most common complaints on admission were cognitive impairment, disturbance in consciousness, ataxia, and gait disturbance. CSF protein 14-3-3 was positive in $100 \%$ of patients. The most common findings were periodic sharp and wave complexes on EEG, cortical or putamen and caudate nucleus hyperintensity, cortical and cerebellar atrophy on MRI. One of the patients was diagnosed as variant CJD, and the others were diagnosed as the sporadic form. Conclusions: CJD should be kept in mind in patients with myoclonus or ataxia accompanied by progressive cognitive impairment. Neuroimaging, serial EEG recordings, CSF analysis, and histopathologic examination should be performed for diagnosis.
\end{abstract}

Keywords: Prion diseases, Creutzfeldt-Jakob disease, Cognitive impairment, Myoclonus, Electroencephalography

\section{ÖZET}

Giriș: Önemli bir halk sağlığı sorunu olan demans primer ve sekonder demans olmak üzere iki gruba ayrılmaktadır. Çok nadir olarak görülen CreutzfeldtJakob hastalı̆̆ $(\mathrm{CJH})$, hızlı progresif seyir gösteren bir sekonder demans nedenidir. CJH insanları ve hayvanları etkileyebilen enfeksiyöz spongioform ensefalopatilerden, ölümcül bir nörodejeneratif hastalıktır. Dört formu olan hastalı̆̆ın en sık görülen formu olan sporadik CJH olgularında progresif kognitif bozukluk, miyoklonus ve ataksi tipik klinik tablodur. Bu çalıșmada Nörolojik yoğun bakım ünitesinde tanı alan CJH olgularının demografik, klinik ve laboratuvar bulgularını tartışmayı amaçladık. Yöntem: Retrospektif olarak planlanan bu çalışmaya 16 hasta dahil edildi. Hastaların yaş, cinsiyet, başvuru șikayetleri, semptom bașlangıcından mortaliteye kadar geçen süre, nörolojik muayene, beyin manyetik rezonans görüntüleme (MRG), elektroensefalografi (EEG) ve beyin omurilik sıvısında (BOS) protein 14.3.3 durumu kaydedildi. Bulgular: Ortalama yaş $61.18 \pm 9.1$ (37-73) olan hastaların başvuruda en sık karșılașılan şikayetleri sırayla bilişsel bozukluk, bilinç bozukluğu, ataksi ve yürüme bozukluğu idi. BOS'ta protein 14.3 .3 hastaların \% 100'ünde pozitifti. En sı saptanan EEG bulgusu periyodik keskin dalga kompleksleri, en sık saptanan beyin MRG'de kortikal veya putamen ve kaudat nükleus hiperintensitesi ve kortikal ve serebellar atrofi idi. Bir hasta varyant $\mathrm{CJH}$, diğer hastalar ise sporadik form olarak değerlendirildi. Sonuç: Progresif kognitif bozukluk ve eşlik eden miyoklonus veya ataksi varlığında CJH tanısı mutlaka akılda tutulmalıdır. Tanı için beyin görüntüleme, seri EEG kayıtlamaları, BOS analizi ve yapılabilirse histopatolojik inceleme yapılmalıdır.

Anahtar Kelimeler: Creutzfeldt-Jacob hastalığı, elektroensefalografi, kognitif bozukluk, miyoklonus, prion hastalıkları

Received date / Geliș tarihi: 17.04.2020, Accepted date / Kabul tarihi: 26.05 .2020

${ }^{1}$ Department of Neurology, Faculty of Medicine, Cukurova University, Adana, 01330, TURKEY.

*Address for Correspondence / Yazışma Adresi: Turgay Demir, Cukurova University, Faculty of Medicine, Department of Neurology, Adana, 01330, TURKEY.

E-mail: drtdemir@gmail.com, tdemir@cu.edu.tr

Demir et al., Creutzfeldt-Jacob Disease, as a rare cause of dementia should not be forgotten: Single-Center Experience. TJFMPC, 2020;14(3):407-413.

DOI: $10.21763 / \mathrm{tjfmpc} .721832$ 


\section{INTRODUCTION}

Dementia, which is an important public health problem, is very common in the society especially in the older age group and it is divided into two groups as primary and secondary dementia. While the most common cause of primary dementia is Alzheimer's Disease, the most common cause of secondary dementia is vascular dementia.

One of the causes of secondary dementia is Creutzfeldt-Jakob disease (CJD) and it is the prototype of progressive dementia.

CJD is a very rare cause of dementia and fatal neurodegenerative disorder of infectious spongiform encephalopathy that can affect humans and animals. ${ }^{1}$ It is characterized by the accumulation of pathologic prion protein in the central nervous system. ${ }^{2}$ The incidence of the disease varies between 0.5 and 1.5 per million and is similar in both sexes. Although the age of onset of the disease is often over 65 years, cases that encompass all ages between 14 and 92 years have been reported to date. ${ }^{3}$

The most common form of the disease is sporadic CJD (sCJD) of unknown etiology, with $85 \%$ frequency, followed by the familial (fCJD), variant (vCJD), and iatrogenic (iCJD) forms. ${ }^{4}$ The most typical clinical presentation of SCJD includes ataxia, progressive cognitive impairment, and myoclonus. In addition, psychiatric, visual, cerebellar, pyramidal, and extrapyramidal findings are common in the course of the disease. ${ }^{5}$ Although the disease does not have precisely known risk factors, some forms have been thought to be associated with various factors. Usually, the age of onset is 60 years of age for SCJD, at an earlier age for fCJD, and on the third to the fourth decade for vCJD. fCJD cases have been thought to have an autosomal dominant inheritance. iCJD has been known to have the risk of contamination of brain tissue. There was evidence that vCJD may develop by consuming contaminated animal meat.

Currently, no cure is available for CJD. Although the mean interval from diagnosis to death in SCJD cases has been reported to be 4-6 months, there have been reported cases of surveillance from weeks to several years. ${ }^{6}$ Female sex and younger age at onset were associated with longer survival. ${ }^{7}$

Early diagnosis of the disease is important in terms of reducing the relatives of patients seeking medical treatment and prevention of iatrogenic transmission. CJD is one of the preliminary diagnoses that should be evaluated in patients with middle-advanced age presenting with progressive cognitive complaints, myoclonia, and movement disorders, balance disorder, or psychiatric complaints in primary care.

In this article, we aimed to discuss the demographic, clinical, and laboratory findings of CJD cases diagnosed at our neurology intensive care unit (NICU).

\section{METHODS}

This single-center retrospective study was carried out in our tertiary healthcare center in Adana, Turkey after obtaining the approval of the local ethics committee (Cukurova University, Faculty of Medicine, Ethics Committee for Non-invasive Clinical Research -Decision No: 2019-10-92). In this study, the archived files of 3,841 patients who stayed at our tertiary hospital NICU between 2000 and 2019 were reviewed; 17 patients who were diagnosed as CJD were included. Patients who had no available medical documentation were excluded. Age, sex, symptoms on the onset, the interval between symptom onset and mortality, neurologic examination findings, cerebral magnetic resonance imagination (MRI), electroencephalography (EEG), and protein 14.3.3 status of the cerebrospinal fluid (CSF) were recorded. The diagnosis of CJD was made based on the diagnostic criteria for SCJD surveillance (Table 1). ${ }^{8}$

The IBM Statistical Package for the Social Sciences Version 20 was used to analyze the data obtained from the assessments. The descriptive statistics of the quantitative data were presented as a minimum, maximum, mean \pm standard deviation (SD), or median, whereas qualitative data were presented as number (n) and frequency (\%). 


\begin{tabular}{ll|}
\hline $\begin{array}{l}\text { Table 1. Diagnostic criteria for the surveillance of sporadic Creutzfeldt-Jakob disease from January 1, } \\
2017^{8}\end{array}$ \\
\hline $1.1 \quad$ DEFINITE \\
\hline & $\begin{array}{l}\text { Progressive neurologic syndrome AND } \\
\text { Neuropathologically, immunohistochemically, or biochemically confirmed }\end{array}$ \\
\hline $1.2 \quad$ PROBABLE \\
\hline
\end{tabular}

1.2.1 I + two of II and typical electroencephalogram ${ }^{\mathrm{a}}$

OR 1.2.2 I + two of II and typical brain magnetic resonance imaging findings ${ }^{b}$

OR 1.2.3 I + two of II and positive cerebrospinal fluid (CSF) protein 14-3-3

OR 1.2.4 progressive neurologic syndrome and positive real-time quacking-induced conversion in CSF or other tissues

\begin{tabular}{ll}
\hline 1.3 & POSSIBLE \\
\hline & I + two of II + duration of $<2$ years \\
I & Rapidly progressive cognitive impairment \\
II & A Myoclonus \\
& B Visual or cerebellar problems \\
& C Pyramidal or extrapyramidal features \\
& D Akinetic mutism \\
\hline
\end{tabular}

a Generalized periodic complexes
${ }^{\mathrm{b}}$ High signal in the caudate/ putamen or at least two cortical regions (temporal, parietal, occipital) on brain magnetic resonance imaging,
either diffusion-weighted imaging, or fluid-attenuated inversion recovery

\section{RESULTS}

Sixteen patients were included in the study [10 men, mean age $61.18 \pm 9.1$ years (range, 37-73 years)]. The most common symptom on onset was cognitive impairment, followed by gait disturbances. The most frequently observed neurologic examination finding was cognitive decline. The protein 14.3.3 level in the CSF could not be measured in 1 patient, but it was positive in 15 patients. The mean duration of follow-up was five months, and one newly diagnosed patient remains alive and is still being followed-up (Table 2).

\begin{tabular}{|c|c|c|c|}
\hline & $\begin{array}{c}\text { Female } \\
\text { n }(\%)\end{array}$ & $\begin{array}{l}\text { Male } \\
\text { n (\%) }\end{array}$ & $\begin{array}{l}\text { Total } \\
\text { n (\%) }\end{array}$ \\
\hline Patient number & $6(37.5)$ & $10(62.5)$ & $16(100)$ \\
\hline Age $($ mean $\pm \mathrm{SD})$ & $62.33 \pm 6.47(54-72)$ & $60.5 \pm 10.64(37-73)$ & $61.18 \pm 9.1(37-73)$ \\
\hline \multicolumn{4}{|l|}{ Symptom on onset } \\
\hline Psychiatric & $2(33.3)$ & $3(30)$ & $5(31.25)$ \\
\hline consciousness & $6(100)$ & $9(90)$ & $15(93.75)$ \\
\hline disturbance & $0(0)$ & $1(10)$ & $1(6.25)$ \\
\hline Speech disorder & $1(16.6)$ & $8(80)$ & $9(56.25)$ \\
\hline Ataxia/ gait disturbance & $1(16.6)$ & $0(0)$ & $1(6.25)$ \\
\hline Seizure & $1(16.6)$ & $3(30)$ & $4(25)$ \\
\hline Myoclonus & $1(16.6)$ & $0(0)$ & $1(6.25)$ \\
\hline Anorexia & $1(16.6)$ & $0(0)$ & $1(6.25)$ \\
\hline \multicolumn{4}{|l|}{ Sleep disorder } \\
\hline Initial neurologic examination findings & & & \\
\hline Cognitive impairment & $4(66.2)$ & $8(80)$ & $12(75)$ \\
\hline Akinetic mutism & $2(33.2)$ & $1(10)$ & $3(18.75)$ \\
\hline Dysarthria & $1(16.6)$ & $1(10)$ & $2(12.5)$ \\
\hline Cerebellar impairment & $1(16.6)$ & $4(40)$ & $5(31.25)$ \\
\hline Extrapyramidal findings & $4(66.2)$ & $3(30)$ & $7(43.75)$ \\
\hline Myoclonus & $1(16.6)$ & $5(50)$ & $6(37.5)$ \\
\hline Protein $14-3-3$ positivity in the CSF & $5(100)$ & $10(100)$ & $15(100)$ \\
\hline Mean survey & $4.1(2-6)$ & $5.5(1-12)$ & $5(1-12)$ \\
\hline
\end{tabular}

CSF, cerebrospinal fluid; SD, standard deviation 
A 72-year-old man had epilepsy. A 37-year-old man who presented with cognitive and psychiatric symptoms was diagnosed as vCJD. Periodic sharpwave complexes (PSWC) were the most common EEG finding, and the most common MRI findings were cortical or putamen and nucleus caudatus hyperintensity, and cortical and cerebellar atrophy
(Table 3). In the first EEG recording, only 37.5\% $(\mathrm{n}=6)$ of the patients had characteristic PSWC findings. Hyperintensity on MRI was seen in the deep gray matter in $37.5 \%(n=6)$, in the cortex in $43.75 \%(\mathrm{n}=7)$, and in both deep gray matter and cortex in $25 \%(n=4)$.

\begin{tabular}{|c|c|c|c|c|c|c|}
\hline $\begin{array}{l}\text { Patient } \\
\text { number }\end{array}$ & Age & $\overline{\text { Sex }}$ & EEG at admission & $\begin{array}{l}\text { EEG at } \\
\text { follow-up }\end{array}$ & \multicolumn{2}{|c|}{ Brain MRI at admission } \\
\hline 1 & 54 & $\mathrm{~F}$ & PSWC & GPED & & Bilateral severe cerebral atrophy \\
\hline 2 & 57 & M & Diffuse slowing & PSWC & $\begin{array}{l}\text { Bilateral putamen and caudate } \\
\text { nucleus hyperintensity }\end{array}$ & $\begin{array}{l}\text { Bilateral frontal and temporal } \\
\text { hyperintensity }\end{array}$ \\
\hline 3 & 67 & $\mathrm{~F}$ & Diffuse slowing & PSWC & Bilateral putamen hyperintensity & $\begin{array}{l}\text { Severe cerebral and cerebellar } \\
\text { atrophy }\end{array}$ \\
\hline 4 & 58 & $\mathrm{~F}$ & PSWC & GPED & $\begin{array}{l}\text { Bilateral putamen and caudate } \\
\text { nucleus hyperintensity }\end{array}$ & $\begin{array}{l}\text { Right temporal and parietal } \\
\text { hyperintensity }\end{array}$ \\
\hline 5 & 72 & $\mathrm{M}$ & $\begin{array}{l}\text { Abnormal background } \\
\text { activity }\end{array}$ & PSWC & & Bilateral frontal hyperintensity \\
\hline 6 & 72 & $\mathrm{~F}$ & Normally & PSWC & & Cerebral and cerebellar atrophy \\
\hline 7 & 60 & $\mathrm{~F}$ & $\begin{array}{l}\text { Abnormal background } \\
\text { activity }\end{array}$ & PSWC & & Bilateral frontal hyperintensity \\
\hline 8 & 63 & $\mathrm{M}$ & $\begin{array}{l}\text { Abnormal background } \\
\text { activity }\end{array}$ & PSWC & & Cerebral and cerebellar atrophy \\
\hline 9 & 79 & M & $\begin{array}{l}\text { Abnormal background } \\
\text { activity }\end{array}$ & PSWC & & $\begin{array}{l}\text { Severe cerebral and cerebellar } \\
\text { atrophy }\end{array}$ \\
\hline 10 & 60 & $\mathrm{M}$ & PSWC & PSWC & $\begin{array}{l}\text { Bilateral putamen and caudate } \\
\text { nucleus hyperintensity }\end{array}$ & \\
\hline 11 & 71 & $\mathrm{M}$ & PSWC & PSWC & & Cerebral and cerebellar atrophy \\
\hline 12 & 55 & M & $\begin{array}{l}\text { Abnormal background } \\
\text { activity }\end{array}$ & PSWC & & $\begin{array}{l}\text { Severe cerebral and cerebellar } \\
\text { atrophy }\end{array}$ \\
\hline 13 & 61 & $\mathrm{M}$ & $\begin{array}{l}\text { Abnormal background } \\
\text { activity }\end{array}$ & PSWC & & Cerebral and cerebellar atrophy \\
\hline 14 & 63 & $\mathrm{~F}$ & PSWC & PSWC & $\begin{array}{l}\text { Bilateral putamen and caudate } \\
\text { nucleus hyperintensity }\end{array}$ & $\begin{array}{l}\text { Right frontal and temporal } \\
\text { hyperintensity }\end{array}$ \\
\hline 15 & 55 & $\mathrm{M}$ & $\begin{array}{l}\text { Abnormal background } \\
\text { activity }\end{array}$ & PSWC & $\begin{array}{l}\text { Bilateral putamen and caudate } \\
\text { nucleus hyperintensity }\end{array}$ & Cerebral and cerebellar atrophy \\
\hline 16 & 37 & M & PSWC & PSWC & & $\begin{array}{l}\text { Right temporal and parietal } \\
\text { hyperintensity }\end{array}$ \\
\hline
\end{tabular}

EEG, electroencephalography; F, female; GPED, generalized periodic epileptiform discharges; M, male; MRI, magnetic resonance imagination; PSWC, periodic sharp and wave complexes

\section{DISCUSSION}

Prion diseases are a group of neurodegenerative diseases that have long incubation periods and progressive clinical symptoms. Behavioral problems, headache, loss of appetite, weight loss, fear, and psychotic symptoms can be seen in the prodromal phase of CJD, which accounts for more than $90 \%$ of prion diseases. Onset with psychiatric symptoms is not uncommon. For this reason, patients first consult the psychiatry outpatient clinics and may be diagnosed as psychosis and depressive disorder. In this study, the initial symptoms were psychiatric complaints in five cases, loss of appetite in one case, and sleep disturbance in one case. The most common psychiatric complaints were depressive symptoms and paranoid thoughts.

Progressive cognitive impairment, myoclonus, and ataxia predominate in CJD cases that present with obvious clinical findings. Impairment of consciousness, as well as pyramidal, extrapyramidal, and cerebellar signs, may be noted on neurologic examination. Usually, most patients present with mutism in the advanced stage. The initial clinical manifestations of our 16 patients were cognitive impairment in 12 (75\%), extrapyramidal signs in $7(43.75 \%)$, cerebellar signs, and myoclonus in $5(31.25 \%)$, and impairment of consciousness in 3 (18.75\%). 
Clinical exam, EEG, brain MRI, and CSF analysis are crucial for the diagnosis of the disease, and the definitive diagnosis can be made by histopathologic analyses. Unfortunately, a brain biopsy was not possible to perform in our patients. Therefore, all of our patients were diagnosed as possible CJD (15 cases of SCJD, 1 case of vCJD) based on history, clinical course, neurologic examination, serial EEG examinations, brain MRI, and CSF results of protein 14-3-3. In another series of 16 cases reported from Turkey, all cases were diagnosed as sCJD. ${ }^{9}$ vCJD accounts for less than $1 \%$ of all prion diseases. ${ }^{10}$ Although vCJD cases are typically seen at a younger age (mean, 26 years), they present with psychiatric symptoms, such as anxiety, agitation, depression, and psychosis. Therefore, patients are usually diagnosed as primary psychiatric disorders before the diagnosis of vCJD. ${ }^{11}$ A few months after the onset of psychiatric symptoms, neurologic symptoms, such as cognitive and cerebellar dysfunction, dysesthesias, and involuntary movements, appear.$^{10}$ Dementia and kinetic mutism predominate in the later stages of the disease.

In the early stage of CJD, diffusion MRI may show increased signal in the cortex or caudate and anterior putaminal localization. In this study, only $37.5 \%$ of patients had bilateral caudate and putaminal hyperintensity on brain MRI (Image 1). In the middle stage, unilateral or bilateral and symmetric or asymmetric lesions can be seen in the same localization. During this period, lesions on the FLAIR sequence may be better visualized, but diffusion may not be apparent on MRI, and generalized atrophy and ventricular dilatation can be observed in all sequences. In the advanced stage, generalized atrophy and ventricular dilatation are noteworthy. In some cases, a slight signal increase in the cortex or basal ganglia may be seen on DWI sequences. ${ }^{12,13}$
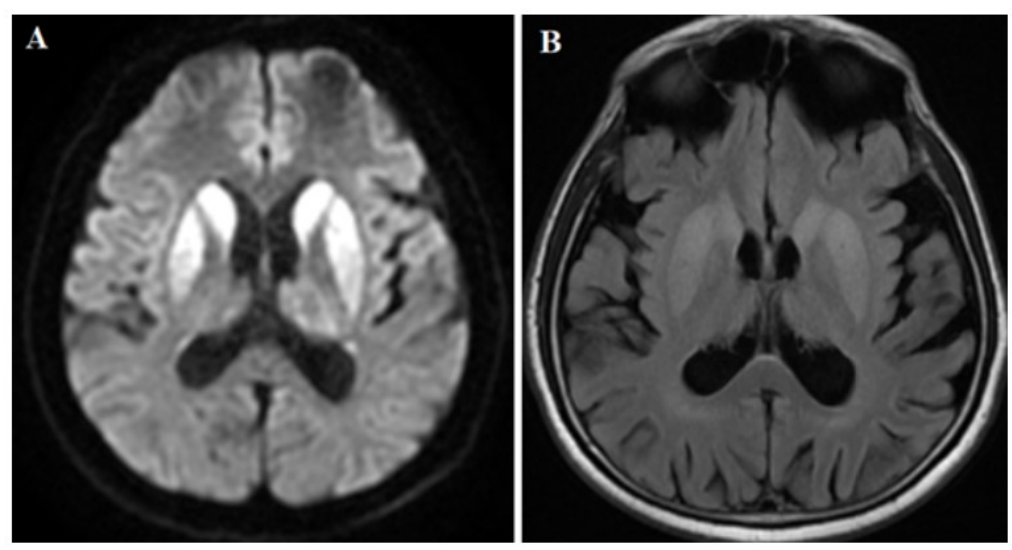

Image 1. A. Bilateral hyperintense signals in the caudate and putamen (hockey stick sign) on diffusionweighted (DWI) MRI. B. FLAIR sequence MRI shows (Patient 15)

EEG is a very useful tool for the diagnosis of CJD. In $67 \%$ to $95 \%$ of patients, the characteristic EEG pattern during the disease is periodic synchronous biphasic or triphasic sharp-wave complexes, which were reported to be $67 \%$ sensitive and $86 \%$ specific for CJD. ${ }^{14}$ In the early stage of the disease, EEG is normal or may show nonspecific deceleration. Occasionally, the first finding may be intermittent frontal rhythmic delta activity. ${ }^{15}$ The characteristic PSWCs may appear weeks or months after the onset of the disease and typically comprise sharp waves, spikes, or triphasic waveforms with a frequency of 1-2 Hertz.$^{16}$ In this study, we detected PSWCs in 12 patients by serial EEG monitoring (Image 2). Moreover, PSWCs can differentiate CJD cases from the other prion diseases; these can be seen in SCJD and FCJD cases but not in vCJD cases. ${ }^{17}$ Although PSWCs may not be seen in the early stages of the disease, they may occur later in the disease course. Therefore, serial EEG recordings are very important fo the diagnosis of patients with suspected CJD. In the terminal period, PSWCs are not seen because of very low voltage activity and the subsequent electro cerebral inactivity. PSWCs may be masked by benzodiazepines and barbiturates, and these activities are much less common in patients with iCJD. ${ }^{18}$ 


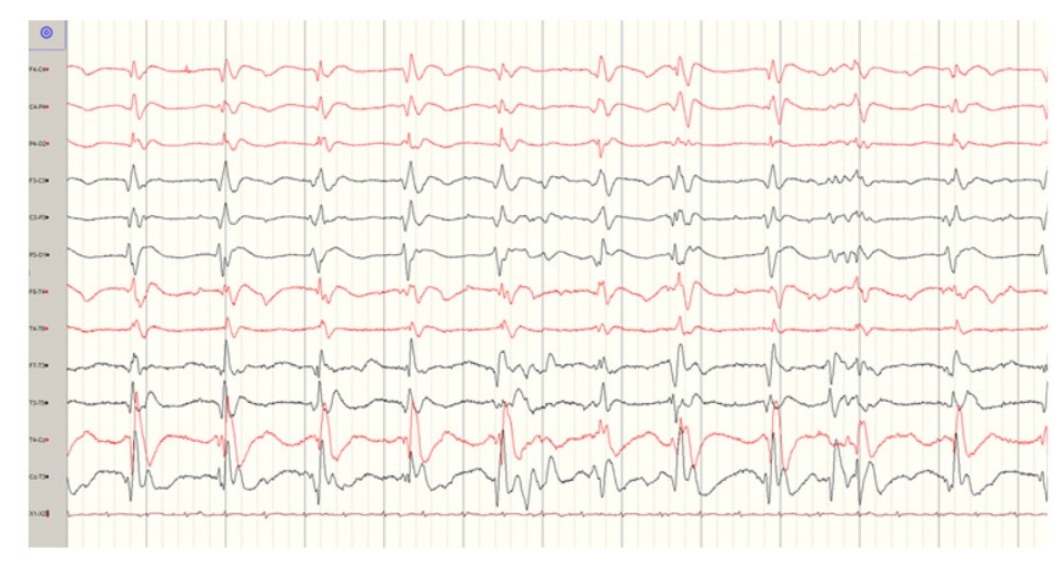

\section{Image 2. Periodic sharp-wave complexes in EEG of patient 4}

Previous studies suggested an association between MRI findings and EEG activities. ${ }^{19}$ Several studies have reported that PSWC activities were associated not with the deep gray matter but with cortical lesions, suggesting that cortical lesions are the source of PSWC activity. ${ }^{20}$ Contrary to published literature, this study showed one patient in whom there was no significant relationship between the EEG and MRI findings in the first week of clinic admission (Table 3). There had been studies on the determination of some proteins in the CSF for CJD diagnosis; of these proteins, the most commonly used for CJD diagnosis has been protein 14.3.3. The other proteins that have been investigated for CJD diagnosis were S100 protein, neuron specific enolase, thymosin $\beta 4$, and tau protein. ${ }^{21}$ Although protein 14.3 .3 positivity for the diagnosis of CJD has been reported to have varying sensitivity and specificity, it was found to be $92 \%$ sensitive and $80 \%$ specific in one study. ${ }^{22}$ This meant that protein 14.3.3 negativity does not exclude the diagnosis and that protein 14.3 .3 positivity does not always indicate CJD. False positivity may be present in herpes simplex encephalitis, paraneoplastic diseases, cerebral metastases, hypoxic encephalopathy, and metabolic encephalopathy. ${ }^{23}$ Therefore, along with clinical findings, protein 14.3 .3 positivity, as well as characteristic EEG and MRI findings, can reinforce the diagnosis of CJD. In our study, the rate of protein 14.3 .3 positivity in the CSF was $100 \%$. In recent years, the real-time quacking-induced

\section{REFERENCES}

1. Green AJE. RT-QuIC: a new test for sporadic CJD. Practical Neurol 2019;19:49-55.

2. Feketeová E, Jarčušková D, Janáková A, Rozprávková A, Cifráková Z, Farkašová-Inaccone $S$ et al. Creutzfeldt-Jakob Disease Surveillance in eastern Slovakia from 2004 to 2016. Cent Eur J Public Health 2018; 26 (Suppl):37-41. conversion was developed and found to be $92 \%$ sensitive and $98.5 \%$ specific for the diagnosis of CJD. ${ }^{24}$

Primary care physicians are the most important health personnel in the early diagnosis of the disease. It is the primary care physician who often encounters the patient first. They also encounter these patients in the advanced stages of the disease in CJD patients' stage care services. Important suggestions to keep in mind in the care of these patients are as follows; 1-Current evidence suggests that there is no risk of disease transmission through normal social or routine contact to healthcare workers, family members or others. 2- Families do not need to take precautions other than routine infection control practices during the care of these patients. 3- Feeding utensils, feeding tubes, suction tubes, razors or personal care items do not require special precautions. 4Physicians following CJD patients should inform the staff responsible for the laboratory, morgue and funeral procedures at risk of contact with high or low infective materials. ${ }^{25}$

In conclusion, CJD should be kept in mind in patients with progressive cognitive impairment, when there are accompanying myoclonuses or ataxia and precedent psychiatric symptoms. Diagnostic neuroimaging, serial EEG recordings, CSF analysis, and, if possible, the histopathologic examination should be performed.

3. Brown P, Budka H, Cervenakova L, Collie DA, Green A, Ironside JW, et al. WHO manual for surveillance of human transmissible spongiform encephalopathies including variant CreutzfeldtJakob disease. Geneva:WHO; 2003.p 12-3.

4. Brandel JP, Delasnerie-Lauprêtre N, Laplanche JL, Hauw JJ, Alpérovitch A. Diagnosis of 
Creutzfeldt-Jakob disease: effect of clinical criteria on incidence estimates. Neurology 2000;54(5):1095-9.

5. Gambetti P, Kong Q, Zou W, Parchi P, Chen SG. Sporadic and familial CJD: classification and characterisation. Br Med Bull 2003;66:213-39

6. Johnson DY, Dunkelberger DL, Henry M, Haman A, Greicius MD, Wong K et al. Sporadic Jakob-Creutzfeldt disease presenting as primary progressive aphasia. JAMA Neurol. 2013;70(2):254-7.

doi:10.1001/2013.jamaneurol.139

7. Pocchiari M, Puopolo M, Croes EA, Budka H, Gelpi E, Collins S, et al. Predictors of survival in sporadic Creutzfeldt-Jakob disease and other human transmissible spongiform encephalopathies. Brain. 2004;127(pt 10):2348-59. doi:10.1093/brain/awh249

8. Mackenzie G, Will R. Creutzfeldt-Jacob disease: recent developments. F1000Res 2017;6:2053. doi: 10.12688/f1000research.12681.1

9. Collie DA, Sellar RJ, Zeidler M, Colchester AC, Knight R, Will RG, et al. MRI of Creutzfeldt-Jakob disease: imaging features and recommended MRI protocol. Clin Radiol 2001; 56:726.

10. Geschwind MD. Prion diseases. Continuum. 2015;21: 1612-38.

11. Dervaux A, Vicart S, Lopes F, Le Borgne MH. Psychiatric manifestations of a new variant of Creutzfeldt-Jakob disease. Apropros of a case. Encephale. 2001;27:194-7.

12. Ukisu R, Kushihashi T, Kitanosono T, Fujisawa H, Takenaka H, Ohgiya Y, et al. Serial diffusionweighted MRI of Creutzfeldt-Jakob disease. AJR Am J Roentgenol 2005; 184:560.

13. Bavis $J$, Reynolds $P$, Tegeler C, Clark $P$. Asymmetric neuroimaging in Creutzfeldt-Jakob disease: a ruse. J Neuroimaging 2003; 13:376

14. Steinhoff BJ, Zerr I, Glatting M, SchulzSchaeffer W, Poser S, Kretzschmar HA. Diagnostic value of periodic complexes in Creutzfeldt-Jakob disease. Ann Neurol 2004; 56:702.

15. Hansen HC, Zschocke S, Sturenburg HJ, Kunze $\mathrm{K}$. Clinical changes and EEG patterns preceding the onset of periodic sharp wave complexes in Creutzfeldt-Jakob disease. Acta Neurol Scand. 1998;97:99-106.
16. Appel S, Cohen OS, Chapman J, Gilat S, Rosenmann H, Nitsan $Z$. The associaon of quantitative EEG and MRI in Creutzfeldt-Jacob Disease. Acta Neurol Scand 2019; 140:366-71.

17. Collins SJ, Sanchez-Juan P, Masters CL, Klug GM, van Duijn C, Poleggi A, et al. Determinants of diagnostic investigation sensitivities across the clinical spectrum of sporadic Creutzfeldt-Jakob disease. Brain 2006; 129:2278.

18. Bortone E, Bettoni L, Giorgi C, Terzano MG, Trabattoni GR, Mancia D. Reliability of EEG in the diagnosis of Creutzfeldt-Jakob disease. Electroencephalogr Clin Neurophysiol 1994; 90:323.

19. Na DL, Suh CK, Choi SH, Moon HS, Seo DW, Kim SE, et al. Diffusion-weighted magnetic resonance imaging in probable Creutzfeldt-Jakob disease: a clinical-ana- tomic correlation. Arch Neurol. 1999;56:951-7.

20. Mizobuchi M, Tanaka C, Sako K, Nihira A, Abe T, Shirasawa A. Correlation between periodic sharp wave complexes and diffusion- weighted magnetic resonance images in early stage of Creutzfeldt- Jakob disease: a report of two cases. Seizure. 2008;17:717-22.

21. Zanusso G, Fiorini M, Farinazzo A, Gelati M, Benedetti MD, Ferrari S, et al. Phosphorylated 143-3zeta protein in the CSF of neuroleptic-treated patients. Neurology 2005; 64:1618.

22. Satoh J, Kurohara K, Yukitake M, Kuroda Y. The 14-3-3 protein detectable in the cerebrospinal fluid of patients with prion-unrelated neurological diseases is expressed constitutively in neurons and glial cells in culture. Eur Neurol 1999; 41:216.

23. Chapman T, McKeel DW Jr, Morris JC. Misleading results with the 14-3-3 assay for the diagnosis of Creutzfeldt-Jakob disease. Neurology 2000; 55:1396.

24. Foutz A, Appleby BS, Hamlin C, Liu X, Yang $\mathrm{S}$, Cohen $\mathrm{Y}$, et al. Diagnostic and prognostic value of human prion detection in cerebrospinal fluid. Ann Neurol 2017; 81:79-92.

25. Alberta Health and Wellness. Public Health Disease Management Guidelines. Creutzfeldt-Jacob Disease: Classic and variant. 2003-2018. p.11 